\title{
MENEGAKKAN HAK ASASI MANUSIA, MENGGUGAT DISKRIMINASI
}

\author{
Todung Mulya Lubis*
}

\begin{abstract}
Abstrak
Reformation steps must be seen as part of change that's happened in international sphere where democracy and human rights been become new civilization pillar. Under that milieu then the author reasons might not hide several sensitive problems on ethnic, race and religion (SARA). Reformation itself that's believed would delivery freedom from prior authoritarian regime but also has raised another authoritarian in fundamentalism form. Discrimination as target to annihilate in recent time has change into many privilege been asked for local (native) person also by their nepotism. The author submits moralistically approach why more sophisticated to build human rights consciousness. Constitutional legitimating has been stipulated to make Indonesia free from discrimination that still has strong roots.
\end{abstract}

Kata kunci: hukum konstitusi, hak asasi manusia, UUD 1945, diskriminasi

"The law has made him equal, but man has not" Clarence Darrow ${ }^{I}$

\section{Pengantar}

Sekitar tahun 1926, seorang pekerja kulit hitam, Henry Smith, pindah ke pemukiman orang kulit putih di kawasan Detroit, kota yang dikenal sebagai pusat industri otomotif. Dinamika pertumbuhan ekonomi yang pesat membawa banyak pekerja kulit hitam mengadu nasib, dan Henry Sweet adalah salah satu diantaranya. Henry Sweet berhasil dalam pekerjaannya dan memutuskan untuk membeli rumah baru di kawasan pemukiman orang kulit

${ }^{1}$ Clarence Darrow, "I Believe In The Law Of Love", Dalam Speeches That Changed The World, London, Quercus Publishing Ltd, 2005, hal 73. 
putih. Kelompok fundamentalis kulit putih yang rasialis, Ku Klux Klan, menghasut massa untuk mengobarkan semangat anti kulit hitam dan mengusir Henry Sweet. Dakam menghadapi demonstrasi massa kulit putih, Henry Sweet terpaksa membela diri dan menembak. Salah satu pelurunya mengena seorang kulit putih yang kemudian meninggal. Henry Sweet dituduh melakukan pembunuhan dan diancam dengan pidana mati. Dia diadili di pengadilan negeri Detroit dalam suasana yang sangat emosional dimana semua anggota dewan jurynya berkulit putih. Disinilah dia dibela oleh seorang ahli hukum terkemuka, advokat pembela hak asasi manusia, Clarence Darrow, yang secara berani melawan arus dan menuduh semua ini sebagai kebencian rasial. Opini public yang diarahkan untuk menghukum mati Henry Sweet dikalahkan oleh Clarence Darrow yang membuat pembelaan yang memukau. Antara lain dikatakan oleh Clarence Darrow,

I am the last one to come here to stir up race hatred, or any other hatred. I do not believe in the law of hate. I may not be true to my ideals always, but I believe in the law of love, and I believe you can do nothing with hatred. I would like to see a time when man loves his fellow man, and forgets his colour or his creed. We will never be civilized until that time comes "12

Para juri gemetar mendengar pembelaan yang menyentuh tersebut. Para jury juga semakin tersentuh ketika Clarence Darrow mengatakan,

I know the Negro race has a long road to go. I believe the life of the Negro race has been a life of tragedy, of injustice, of oppression. The law has made him equal, but man has not. ${ }^{3}$

Para jury memutuskan 'not guilty' terhadap Henry Sweet. Pembelaan Clarence Darrow tersebut selalu dijadikan sebagai rujukan bagi banyak advokat yang membela korban kebencian rasial, dan memang pembelaan itu begitu menyentuh perasaan, dan membuat orang merasa bersalah. Buat kita pembelaan itu menunjukkan bahwa rasialisme memang suatu yang berbahaya bagi hak asasi manusia, suatu yang musti terus menerus dilawan. Kami katakan demikian karena dalam wujud lain yang manifest maupun laten kita akan terus menerus menemukan rasialisme yang sering

\footnotetext{
${ }^{2}$ Ibid.

${ }^{3}$ Ibid.
} 
menggunakan topeng diskriminasi. Hanya saja bentuknya tentu bisa jadi lebih halus dan tak terlalu kasat mata.

Kita memang tidak berada di tahun 1926, juga bukan di Detroit. Tetapi tidak akan sulit untuk menerka bahwa persoalan diskriminasi juga terjadi di negeri ini dalam berbagai bentuk. Persoalannya selama ini kita enggan masuk ke dalam wilayah ini karena khawatir akan dituduh melanggar Suku Agama Ras dan Antar Golongan (SARA), suatu terminology yang digunakan oleh pemerintahan Orde Baru untuk membungkam rakyat dan semua usaha untuk mewujudkan harmoni sosial sejati. Semua orang takut dituduh melawan pemerintah, dan karenanya memilih diam. Padahal persoalan diskriminasi itu manifest dan laten ada pada diri kita baik di tubuh pemerintah maupun masyarakat. Persoalan diskriminasi itu dibiarkan bagai api dalam sekam. Seperti kita saksikan sekarang aneka soal diskriminasi itu mencuat ke permukaan karena reformasi yang terjadi menggulirkan pula keterbukaan yang tak dapat membendung terungkapnya praktek diskriminasi tersebut. ${ }^{4}$

\section{Langkah Maju Hak Asasi Manusia.}

Kita semua mengakui bahwa penegakkan hak asasi manusia mengalami kemajuan yang pesat setelah Orde Baru ditumbangkan. Kalau dulu hak asasi manusia itu tak utuh sebagai 'constitutionally guaranteed rights', sekarang keseluruhan pasal 28 UUD 1945 yang sudah diamendemen memberikan kita semua norma-norma hak asasi manusia yang lumayan lengkap, tidak kalah dengan apa yang tertulis di Universal Declaration of Human Rights ${ }^{5}$

Lebih dari itu kita juga sudah memiliki UU No 39/1999 tentang Hak Asasi Manusia yang merupakan kelanjutan (follow up) dari Tap MPR No XVII/MPR/1998. Dari sinilah 'standard setting' hak asasi manusia bergulir sampai akhirnya menuju ke amendemen UUD 1945. Kita juga telah meratifikasi berbagai instrument hak asasi internasional, yang terpenting diantaranya adalah Covenant on Civil and Political Rights (1966) dan Convention On The Elimination Of All Forms Of Racial Discrimination

${ }^{4}$ Lihat Laporan Investigasi, Jakarta, LBH Jakarta dan Kontras, 2008, hal 3-160. Dalam Laporan ini diuraikan berbegai praktek diskriminasi terhadap kelompok Al Qiyadah, Ahmadiah dan Jemaat Gereja di berbagai tempat di Indonesia.

${ }^{5}$ Todung Mulya Lubis, 'In Search Of Human Rights: Legal-Political Dilemmas Of Indonesia's New order, 1996-1990', (Jakarta: Gramedia, 1993). Dalam buku ini diuraikan sejarah panjang pro-kontra hak asasi manusia sejak jaman pergerakan kemerdekaan. 
$(1965)^{6}$. Kesemua ini adalah satu kebijakan yang seratus delapan puluh derajat bertentangan dengan kebijakan hak asasi manusia pada jaman Orde Baru.

Reformasi yang terjadi harus juga dilihat sebagai bagian dari perubahan yang terjadi pada tataran internasional dimana demokrasi dan hak asasi manusia (sekarang ditambah dengan anti-korupsi) memang menjadi pilar dari peradaban baru. Sejak runtuhnya Tembok Berlin maka hak asasi manusia telah menjadi ideologi yang semakin diusung dimana-mana sehingga selalu dikatakan bahwa,

\section{Human rights are undeniably a central dimension of international affairs today. To an unprecedented degree, government and corporate policy as well as social activism are being conducted in their name. ${ }^{7}$}

Secara obyektif kita melihat bahwa penghormatan terhadap hak asasi manusia menunjukkan kemajuan yang sangat significant dimana iklim ketakutan tak lagi dominan. Semua orang memikiliki kebebasan untuk bersuara, berkumpul, berserikat dan beragama. Ratusan partai politik didirikan dan mungkin juga ratusan media diterbitkan. Dimana-mana muncul e-media dalam berbagai bentuknya. Tak heran jika kita melihat berbagai online media sampai pada friendster danfacebook menjadi wahana komunikasi dan informasi baru yang menggerus pasar media-media tradisional. Tentu semua ini tak selamanya menyenangkan karena semua borok bisa dibukakan setiap waktu. Jaman transparansi telah datang dengan segala kebaikan dan keburukannya, dan kita hanya punya satu pilihan yaitu membangun budaya keterbukaan dengan semua akuntabilitas yang melekat bersama keterbukaan tersebut.

Dalam konteks inilah kita tak bisa menutup-nutupi lagi persoalanpersoalan yang dulu kita anggap sensitive dan berbau SARA. Pers bebas dan gerakan hak asasi manusia dari civil society akan terus mengungkapkan borok-borok yang ada pada pemerintah dan masyarakat. Cepat atau lambat semua itu akan muncul ke permukaan. Kami lihat, persoalan diskriminasi adalah salah satu persoalan yang mulai muncul ke permukaan walaupun masih malu-malu. Yang paling banyak muncul adalah diskriminasi dalam hal gender dan agama padahal sesungguhnya amat banyak persoalan

\footnotetext{
${ }^{6}$ Lihat UU No $12 / 2005$ dan UU No $29 / 1999$.
}

${ }^{7}$ Lihat Human Rights Dialogue, Winter 2000, Series 2, Number 1 yang diterbitkan oleh Carnegie Council. 
diskriminasi yang laten yang belum terungkap. Misalnya, diskriminasi dalam lepangan kerja baik di sector pemerintah maupun swasta, dan ini tidak semata-mata antara laki-laki dan perempuan, Islam dan non-Islam, tetapi bisa juga antara suku Jawa dan Luar Jawa, pribumi dan non-pribumi. Persoalan yang di negara-negara maju sudah lama muncul dan mendapatkan penyelesaian konstitusional di negara kita nampaknya baru akan menjadi persoalan. Persoalan diskriminasi di negeri ini masih berada dalam tahap awal, tahap bisik-bisik seolah orang tak boleh tahu bahwa persoalan itu ada. Jadi kalau seorang pribumi yang bekerja di sebuah konglomerasi besar milik warga non-pribumi tak mendapatkan promosi sementara koleganya yang non-pribumi mendapat promosi, maka kita hanya disuguhi gerutuan sambil menyerah menerima keadaan. Tak ada yang berani membawa persoalan ini ke ranah hukum. Tak ada yang mau meniru bagaimana warga kulit hitam dan Latino, misalnya, menggugat perusahaan raksasa seperti General Motor atau Microsoft karena adanya diskriminasi. Tetapi persoalan itu banyak terjadi, dan menurut hemat kami tak lama lagi akan menjadi isu hak asasi manusia yang akan banyak menyedot perhatian kita.

\section{Tiga Diskriminasi}

Ditengah sikap mendua dan malu-malu kita setidaknya bisa menyaksikan tiga persoalan diskriminasi yang menonjol yaitu diskriminasi gender, diskriminasi agama dan diskriminasi budaya. Berbagai studi sudah dilakukan dan meski belum ada satu jalan keluar yang final tetapi kita tetap bisa melihat pasang surut perjuangan melawan diskriminasi tersebut. Dalam hal diskriminasi gender nampaknya persoalan ini sudah mendapat perhatian yang luas dan tak sepenuhnya dilawan oleh pemerintah. Gerakan feminisme yang terorganisasi secara rapi pada tingkat nasional dan internasional berhasil menciptakan wacana emansipasi gender yang dikelola dengan apik. Secara simbolik, misalnya, pemerintah menyambut gugatan diskriminasi gender ini dengan membentuk Menteri Negara Urusan Pemberdayaan Perempuan disamping adanya Komisi Nasional Hak Asasi Manusia Perempuan. Dalam berbagai posisi penting, kaum perempuan sudah mulai mendapat tempat termasuk di Mahkamah Agung dan Mahkamah Konstitusi. Kemudian dari segi standard setting, kita juga melihat sudah banyak ketentuan perundangan yang dilahirkan termasuk ratifikasi terhadap Convention On The Elimination Of All Forms Of Discrimination Against Women (1979).

Tetapi jangan beranggapan bahwa persoalan diskriminasi terhadap perempuan yang sifatnya laten telah selesai. Budaya patriarki masih kokoh 
dalam batang tubuh berbagai produk perundang-undangan dan praktek di lapangan. Jangan heran melihat banyaknya kekerasan terhadap perempuan dalam rumah tangga. Jangan heran melihat berbagai kekerasan terhadap perempuan yang terjadi di lapangan kerja. Dan jangan heran melihat eksploitasi terhadap perempuan baik itu melalui perdagangan perempuan serta pengiriman Tenaga Kerja Wanita (TKW) yang minim perlindungan hukum. Perempuan masih juga dianggap sebagai 'subordinate' dari laki-laki, sadar atau tidak sadar. Disini perlawanan kaum laki-laki terhadap 'affirmative action' sangat gampang dirasakan, dan terakhir ketika Mahkamah Konstitusi memutuskan bahwa penentuan calon legislative terpilih haras melalui suara terbanyak maka semua perjuangan kaum perempuan untuk mendapatkan sepertiga dari jatah calon kursi legislative serta merta dihancurkan ${ }^{8}$. Kemenangan kaum perempuan yang berhasil memasukkan satu calon perempuan dalam setiap tiga calon legislative menjadi sia-sia padahal UU Partai Politik dan UU Pemilu bisa dikatakan sebagai salah satu keberhasilan kaum perempuan untuk memasukkan agenda keadilan gender dalam system politik nasional. ${ }^{9}$

Diskriminasi agama jelas merupakan persoalan yang sudah lama kita hadapi sampai sekarang ini. Konflik horizontal yang terjadi di Maluku dan Poso, misalnya, adalah puncak dari gunung es. Di bawah itu kita akan tak habis-habisnya disuguhi berbagai bentuk diskriminasi antar agama dan juga intra-agama. Pembakaran gereja yang pernah marak di negeri ini adalah manifestasi dari ketegangan antar agama yang selama ini dibenamkan dalam selimut SARA padahal kalau kita membaca pasal 28E dan pasal 29 UUD 1945 maka sesungguhnya tak ada tempat untuk diskriminasi agama. Semua agama, by constitution, diakui dan mempunyai hak hidup yang sama. Coba kita baca pasal 29 (2) UUD 1945 yang berbunyi,

\section{Negara menjamin kemerdekaan tiap-tiap penduduk untuk memeluk agamanya masing-masing dan untuk beribadat menurut agamanya dan kepercayaannya itu.}

Sekarang banyak gereja yang berlokasi di gedung perkantoran karena izin mendirikan gereja di wilayah pemukiman sangat sulit didapatkan. Pertanyaannya: dimana perlindungan negara terhadap kebebasan

${ }^{8}$ Lihat Putusan Mahkamah Konstitusi yang menyatakan bahwa penentuan calon terpilih legislative adalah berdasar suara terbanyak, bukan berdasar nomor urut. Umum.

${ }^{9}$ Lihat UU No 2/2008 tentang Partai Politik dan UU No 10/2008 tentang Pemilihan 
menjalankan agamanya disini? Laporan investigasi terhadap jemaat gereja di Bandung, Jawa Barat, oleh LBH Jakarta dan Kontras menunjukkan bahwa orang-orang Kristen tak bisa menjalankan ibadahnya karena penyegelan terhadap gereja mereka. Keberatan penduduk telah menafikan hak konstitusional kebebasan beragama dan ironisnya, melumpuhkan negara yang mempunyai kewajiban konstitusional menjamin semua warganya untuk menjalankan agamanya ${ }^{10}$

Sebagai negara hukum yang menjunjung tinggi hak asasi manusia, Indonesia adalah rumah buat semua agama meski mayoritas orang Indonesia beragama Islam. Dalam Islam sekalipun keberadaan orang-orang nonMuslim yang disebut dhimma diberikan perlindungan dan kebebasan ${ }^{11}$. Sayangnya realitas kita belum sampai kesana $^{12}$ karena terutama pada beberapa tahun terakhir ini gerakan fundamentalisme agama mulai menguat dan berhasil menggolkan apa yang disebut Perda Syariah di berbagai provinsi dan kabupaten ${ }^{13}$. Tanpa dikatakan hak-hak konstitusional dalam beragama menjadi ternegasikan. Kita seperti mundur ke belakang ketika dulu perdebatan tentang Piagam Jakarta menimbulkan keresahan dalam lapisan masyarakat kita. Padahal seharusnya kita sudah maju ke depan, misalnya, bicara tentang perkawinan antar agama yang juga merupakan hak asasi manusia. Disinilah kita melihat kemenduaan (ambivalency) dalam menegakkan hak asasi manusia.

Ironisnya diskriminasi itu juga terjadi di lingkungan keluarga besar Islam yang memang tidak tunggal (monolitik). Berita mengenai kekerasan terhadap pengikut Al Qiyadah di Sumatera Barat dan Ahmadiyah di Cianjur dan Lombok, misalnya, sudah sering kita baca. Tanpa berpretensi memasuki wilayah teologis kami tetap berpendapat bahwa UUD 1945 sesungguhnya memberi ruang bagi perbedaan tafsir. Sejauh menjalankan ibadah itu dilakukan dengan tertib dan damai, tak ada hak-hak yang dilanggar. Bukankah kepada kita selalu diajarkan 'bagimu agamamu, bagiku agamaku'?

${ }^{10}$ Lihat Laporan Investigasi, Op. Cit., hal 123-127.

"Abdullahi Ahmed An Nairn, "Islam, Islamic Law And Human Rights", dalam Claude E. Welch Jr dan Virginia A Leary, eds, Asian Perspectives On Human Rights, (Boulder, Westview Press, 1990), hal 38.

${ }^{12}$ Provinsi Sumatera Utara adalah provinsi yang terdiri dari berbagai etnis, suku dan agama. Tentu ada ketegangan tetapi ketegangan itu telah terkelola dengan baik selama puluhan tahun sehingga telah tercapai suatu toleransi social yang teruji. Tidak berlebihan jika disebut bahwa Sumatera Utara sebagai 'the real melting pot of ethnics, races and religions'.

${ }^{13}$ Lihat: "Penyeragaman Dan Totalisasi Dunia Kehidupan Sebagai Ancaman Terhadap HAM", (Jakarta: Imparsial, 2007), hal. 15-32. 
Sayangnya ruang untuk berbeda tafsir disini dinihilkan, dan yang tersisa adalah titah kekerasan yang melawan hukum seperti pembakaran, pengusiran dan pengucilan ${ }^{14}$. Disini kita melihat negara melalui aparatnya bukan saja tak berdaya tetapi ikut arus melakukan pembiaran (omission) dan juga intimidasi. Puncak dari diskriminasi agama ini adalah pelarangan terhadap Ahmadiyah, suatu pelanggaran hak asasi manusia oleh negara (an act by the state). Pemerintah Indonesia sepertinya meniru kebijakan pemerintah Pakistan yang melarang Ahmadiyah dengan sanksi pemenjaraan bagi mereka yang tetap menjalankan ajaran Ahmadiyah ${ }^{15}$. Dalil bahwa negara bisa menjadi aktor pelanggaran hak asasi manusia kembali terbukti. Jadi sesungguhnya negara adalah pelindung hak asasi manusia yang rentan, tergantung kepada siapa yang berkuasa. Kebijakan perang melawan terorisme dari George Walker Bush melalui Patriot Act adalah contoh paling kasar dari pelanggaran hak asasi manusia oleh negara.

Diskriminasi ketiga yang banyak mendapat sorotan media adalah diskriminasi budaya. Mencuatnya isu diskriminasi budaya ini berasal dari pembahasan RUU Pornografi yang kontroversial itu. Walau pada esensinya kita merasa prihatin dengan berbagai ekses dari budaya permissive yang melanda dunia termasuk Indonesia tetap saja kita merasa bahwa diajukannya RUU Pornografi bukan sebagai jawaban yang tepat. Pornografi seharusnya bisa ditangani oleh produk perundangan lain seperti Kitab Undang-Undang Hukum Pidana (KUHP) yang memang sudah seharusnya diganti dengan KUHP yang baru yang lebih komprehensif mencakup pelbagai kejahatan kontemporer seperti kejahatan elektronik (cyber crime), terorisme, lingkungan, trans-national corruption dan sebagainya ${ }^{16}$. Tetapi pemerintah dan DPR nampaknya memilih jalan pintas mengajukan RUU Pornografi meski menuai banyak sekali kritikan dari berbagai pihak dan daerah.

RUU Pornografi nampaknya diboncengi oleh agenda politik diskriminatif yaitu politik hukum top-down mengatur moralitas dan budaya. Fokusnya berubah dari anti pornografi menjadi pemaksaan nilai-nilai moralitas dan budaya yang berupa penyeragaman (uniformisasi). Disinilah kemajemukan budaya menjadi terancam karena nilai-nilai moralitas dan budaya itu tak bisa diseragamkan. Jangan heran jika kaum perempuan melawan. Jangan heran kalau orang-orang Bali, Minahasa dan Papua

${ }^{14}$ Lihat: Laporan Investigasi, Op .Cit., hal. 9-54.

${ }^{15}$ Abdullah Ahamed An Nairn, Op. Cit., hal. 41.

${ }^{16}$ RUU KUHP sudah dirancang dan dibahas lebih dari 20 tahun, tetapi sampai hari ini tak pernah final sehingga tak menjadi agenda utama dalam program legislasi nasional (Prolegnas). 
melawan karena implementasi RUU Pornografi yang sekarang sudah menjadi UU Pornografi cenderung menafikan kemajemukan (pluralitas) padahal kekayaan dan kekuatan kita sebagai bangsa terletak justru pada kemajemukan kita. Lagipula para pendiri negara ini mencita-citakan Indonesia yang majemuk, bukan yang monolitik uniformistik. Karena itu banyak yang menolak UU Pornografi ini secara terang-terangan sehingga memang timbul persoalan hukum yaitu bagaimana dengan daerah yang secara terang-terangan menolak memperlakukan UU Pornografi padahal daerah-daerah tersebut berada dalam wilayah hukum Republik Indonesia ${ }^{17}$. Pembangkangan daerah ini, kalau dibiarkan, bisa menjadi preseden yang berbahaya bagi kesatuan kita sebagai bangsa. Pertanyaannya: apakah mungkin pemerintah dan DPR membuat UU dan beberapa daerah menyatakan tak tunduk kepada UU tersebut? Ini persoalan ketatanegaraan yang sangat serius.

Persoalan UU Pornografi ini jika ditelisik lebih jauh sesungguhnya merupakan kelanjutan dari gerakan fundamentalisme yang menolak pluralisme, yang merambah ke wilayah privat, yang dalam format lain mendirikan kembali totalitarianism. Kajian Imparsial tentang Penyeragaman dan Totalisasi Dunia Kehidupan Sebagai Ancaman Terhadap HAM menarik untuk dikutip antara lain,

\begin{abstract}
Salah satu kehendak dan ide totaliteristih paling kontemporer datang dari fundamentalisme. Mirip sebagaimana gejala akhir rezim otoriter, fundamentalisme juga menghendaki suatu totalisasi. Kalau Orde Baru menghendaki menyatunya yang public dan privat dibawah suatu system kekuasaan partikularnya, maka fundamentalisme juga bermaksud demikian, ia juga hendak menyatukan yang public dan yang privat itu dalam suatu kesatuan ideal primordial tertentu dalam hal ini agama. ${ }^{18}$
\end{abstract}

Dalam hal ini negara memang telah terlalu jauh memasuki wilayah privat. Ongkos yang musti dibayar oleh negara adalah risiko bahwa UU Pornografi itu tak akan bisa diberlakukan secara penuh (non-enforcement policy). Ini tentu tidak sehat karena UU dilahirkan untuk diberlakukan,

${ }^{17}$ Lihat Kompas, 22 September 2008. Lihat juga, Ignas Kleden, "Porn Bill Threatens Democratic Freedoms", in The Jakarta Post, October 8, 2008.

${ }^{18}$ Lihat: Penyeragaman Dan Totalisasi Dunia Kehidupan Sebagai Ancaman Terhadap Ham, Op. Cit, hal. 4-5. 
bukan dijadikan perhiasan. Agaknya disinilah kita menemukan apa yang disebut "human rights paradox' yaitu,

On the one hand, the idea of human rights is so powerful that no government in the world today can afford to reject it openly. On the other hand, the most basic and fundamental human rights are being consistently violated in all parts of the world. ${ }^{19}$

Paradoks hak asasi manusia ini akan banyak kita temukan di daerahdaerah yang sekarang menikmati otonomi yang luas. Konstelasi politik yang rentan karena ikatan koalisi jangka pendek telah memungkinkan kompromi politik dimanipulasi. Akibatnya, ideologi semakin digantikan oleh politik kepentingan jangka pendek yang sebagian didikte oleh rekayasa opini publik. Disinilah pluralisme sering dipangkas termasuk oleh partai politik yang platformnya pluralisme..$^{20}$

\section{Realitas Diskriminasi: Antara Ada dan Tiada}

Seperti dikemukakan sebelumnya realitas diskriminasi kita sesungguhnya merupakan realitas sejarah yang sudah ada sejak dulu, dari jaman kerajaan yang feodalistik dan jaman penjajahan yang rasialistik. Lihatlah pasal 163 Indische Staatsregeling (IS) yang membagi rakyat atas 3 golongan yaitu golongan Eropa (Europanen), Timur Asing (Vreemde Oosterlingen) dan Bumiputera (Inlander) ${ }^{21}$. Warisan diskriminasi itu kita temukan dimana-mana termasuk di UUD 1945 ketika dia dirumuskan pertama sekali yaitu dalam pasal tentang warga negara dan pasal tentang syarat mutlak menjadi Presiden yang harus orang Indonesia asli. ${ }^{22}$ UUD RIS dan UUD Sementara juga melanjutkan rumusan diskriminatif tersebut. Tidak aneh jika kita melihat turunan dari hukum dasar tersebut telah pula

${ }^{19}$ Abdullah Ahmed An Nairn, Op. Cit, hal. 33.

${ }^{20}$ Partai Golkar dan Partai Demokrat mendukung pengesyahan RUU Pornografi menjadi UU Pornografi meski platform politik kedua partai itu mendukung pluralisme. Tetapi karena pertimbangan politik jangka pendek, kedua partai tersebut memilih memenangkan kepentingan jangka pendek.

${ }^{21}$ Soepomo, Sistem Hukum Di Indonesia Sebelum Perang Dunia II, Cetakan 15, (Jakarta: Pradnya Paramita, 1997), hal. 23.

${ }^{22}$ Lihat: Naskah Komprehensif Perubahan Undang-Undang Dasar Negara Republik Indonesia Tahun 1945, Buku VIII, hal. 10-22. 
diterjemahkan dalam berbagai kebijakan negara yang dijalankan oleh berbagai departemen pemerintahan. Demikianlah, misalnya, kita melihat orang-orang non-pribumi tak diperbolehkan menjadi tentara dan pegawai negeri. Lalu jabatan-jabatan penting biasanya kebanyakan jatuh ke tangan orang-orang yang berasal dari suku Jawa.

Diskriminasi ini tak seratus persen kelihatan di permukaan karena selalu ada kekecualian, tetapi tak salah kalau orang mengatakan bahwa diskriminasi itu seperti ada dan tiada. 60 tahun lebih kemerdekaan membuktikan bahwa hegemoni suku dan agama cukup dominan. Akibat dari diskriminasi yang ada dan tiada ini adalah meledaknya ketidak puasan luar Jawa seperti yang kita saksikan pada rakyat Aceh dan Papua ${ }^{23}$. Ketidak puasan ini adalah lahirnya klas pengusaha yang didominasi oleh orang-orang non-pribumi keturunan Cina. Kesemua hal diatas membuat Indonesia rentan terhadap berbagai gejolak sosial yang akan menelan biaya sosial, ekonomi dan politik yang mahal.

Indonesia adalah api dalam sekam. Indonesia adalah bom waktu yang bisa saja meledak setiap waktu. Reformasi yang kita yakini akan membebaskan kita dari warisan otoriter masa silam ternyata melahirkan pula otoriterisme lain dalam bentuk fundamentalisme. Diskriminasi yang kita ingin hapus sekarang berganti dengan tuntutan diutamakannya putra daerah dengan segala nepotisme yang merupakan turunannya. Dalam skala kecil kesemua praktek diskriminasi ini kita temukan di berbagai perusahaan dan organisasi. Terus terang realitas ini sangat berbahaya.

Sudah waktunya kita bersiap-siap menyongsong munculnya gugatangugatan terhadap diskriminasi dalam berbagai macam bentuknya. Setidaknya kita akan melihat gugatan terhadap diskriminasi terhadap perempuan yang memang bisa kita rasakan. Juga gugatan karena diskriminasi suku, misalnya, terhadap suku Jawa yang dianggap mendominasi berbagai jabatan di pemerintahan maupun dunia usaha. Gugatan terhadap pengusaha nonpribumi khususnya keturunan Cina akan mulai muncul. Selain itu akan ada gugatan, misalnya, dari para penderita HIV/AIDS yang di berhentikan dari pekerjaannya, atau tak diterima di rumah sakit atau sekolah. Lain lagi gugatan dari kelompok homoseksual dan lesbian. Substansi gugatan akan bermacam-macam baik itu masalah penerimaan (rekrutmen), promosi jabatan, perbedaan gaji, maupun pemukiman serta masalah lainnya.

Kesemua ini adalah persoalan hak asasi manusia yang di negaranegara maju sudah diselesaikan meski tak memuaskan semua orang. Komitmen konstitusional kita terhadap hak asasi manusia akan diuji, dan sebagai bangsa yang melangkah maju dalam berdemokrasi tak ada pilihan

${ }^{23}$ Lihat juga pemberontakan PRRI/Permesta di pertengahan tahun 1950an. 
lain selain menghentikan diskriminasi yang kelak akan menggerogoti demokrasi itu sendiri. Dalam konteks ini kita hanya punya satu pilihan yaitu menjalankan isi pasal 281 (2) yang berbunyi:

Setiap orang berhak bebas dari perlakuan yang bersifat diskrikminatif atas dasar apa pun dan berhak mendapatkan perlindungan terhadap perlakuan yang bersifat diskriminatif itu.

Dan yang lebih penting disini adalah bahwa negara mempunyai kewajiban untuk melindungi warga negaranya seperti yang tertulis dalam pasal 281 (4) yang berbunyi:

Perlindungan, pemajuan, penegakan, dan pemenuhan hak asasi manusia adalah tanggung jawab negara, terutama pemerintah.

Kewajiban negara untuk melindungi ini dalam literatur hukum internasional kontemporer kita kenal sebagai apa yang disebut sebagai 'responsibility to protect', suatu perluasan dari konsep humanitarian intervention. ${ }^{24}$

\section{Menuju Hak Asasi Manusia}

Dengan sekian banyak pasal hak asasi manusia di batang tubuh UUD 1945 maupun perangkat perundangan lainnya, kita tak punya alasan untuk ragu akan komitmen bangsa ini dalam menghormati hak asasi manusia. Kata hak asasi manusia juga sudah menjadi kosa kata umum di masyarakat, $a$ household name. Pemerintah termasuk tentara dan polisi sudah fasih menggunakan kata hak asasi manusia. Polisi sendiri menerbitkan buku saku hak asasi manusia yang jadi panduan bagi setiap polisi $\mathrm{i}^{25}$. Di lingkungan tentara kita juga menemukan hal serupa dimana hak asasi manusia terutama

${ }^{24}$ Francisco Forrest Martin, Stephen J. Schnably, Richard J. Wilson, Jonathan S. Simon dan Mark V. Tusnet, eds, "International Human Rights \& Humanitarian Law", (New York, Cambridge University Press, 2006), hal. 1-6.

${ }^{25}$ Lihat Ham Untuk Polisi, Buku Saku Tentang Hak Asasi Manusia Untuk Polisi, diterbitkan oleh LBH APIK dan Ford Foundation. Buku ini diberi pengantar oleh Mayjen Polisi Ahwil Luthan, ketika itu menjabat sebagi Gubernur Perguruan Tinggi llmu Kepolisian. Lihat juga, Pedoman Prajurit Tni Ad Dalam Penerapan Hak Asasi Manusia, 2000, Diterbitkan Oleh Tentara Nasional Indonesia, Markas Besar Angkatan Darat. 
hukum humaniter dijadikan sebagai rujukan ${ }^{26}$. Jadi hak asasi manusia tidak lagi dilihat dengan antipati sebagai imperialism budaya Barat yang masuk ke tatanan nilai Indonesia atau Asia. Ketegangan yang dulu ada antara hak asasi universal dengan hak asasi particular (Asian values) sudah semakin terpinggirkan walaupun kelompok-kelompok die hard tetap melihat hak asasi manusia itu sebagai sesuatu yang lokal. ${ }^{27}$

Satu problema lain yang bisa menghambat adalah kerangka berfikir kita yang sering terbatasi oleh pengertian 'hak warga negara' (citizens rights). Kalau kita melihat perdebatan para pendiri negara ini ketika merumuskan UUD 1945 maka kita akan melihat bahwa walaupun terminology yang dipakai itu 'hak asasi manusia' (human rights) tetapi yang dimaksudkan adalah hak warga negara. Lihatlah perdebatan menarik antara Soekarno, Hatta, Soepomo dan Yamin, misalnya, semuanya bicara dengan perspektif hak warga negara ${ }^{23}$. Mungkin para pendiri negara pada waktu itu sedang seratus persen focus pada pendirian negara baru sehingga abai pada perbedaan (distinction) filosofis antara hak asasi manusia dan hak warga negara.

Tak bisa dipungkiri bahwa ada sejumlah hak yang hanya dimiliki oleh warga negara seperti hak untuk memilih dan dipilih, tetapi dalam globalisasi yang melanda dunia sekarang ini ada kecenderungan untuk mengikut sertakan semua orang, warga negara dan bukan-warga negara, untuk ikut memberikan keputusan. ${ }^{29}$ Soal pajak dan retribusi, misalnya, adalah kewajiban yang dipikul oleh setiap orang yang berdomisili di satu daerah tanpa membedakan dia warga negara atau bukan-warga negara. Kecenderungan di beberapa negara Eropa dewasa ini adalah mengikutkan pula orang-orang bukan-warga negara untuk memberikan suaranya.

Dalam hal diskriminasi semua orang bisa mengalami terlepas dari apakah dia warga negara atau bukan-warga negara. Banyak kasus dimana warga negara asing mendapat perlakuan diskriminatif tetapi tak mempunyai akses hukum untuk mempersoalkan diskriminasi yang menimpanya. Hal ini

${ }^{26}$ Beberapa ceramah yang penulis lakukan tentang hak asasi manusia menunjukkan adanya perhatian serius untuk mulai memahami hak asasi manusia walau pemahaman itu masih sebatas konteks hukum humaniter (humanitarian law).

27 Virginia A. Leary, "The Asian Region And The International Human Rights Movement", dalam Claude E Welch Jr dan Virginia A Leary, eds, Op. Cit., hal. 13-27.

${ }^{28}$ Todung Mulya Lubis, Op, Cit., hal. 48-85.

${ }^{29}$ Harap dicatat bahwa banyak orang asing yang sudah memperoleh izin menetap (green card) yang artinya sudah menjadi penduduk. 
tentu tidak adil. Pemerintah mempunyai kewajiban untuk menerapkan kebijaksanaan yang menghapuskan diskriminasi bagi setiap orang karena hak untuk tidak didiskriminasi itu adalah hak asasi yang dimiliki oleh setiap orang apalagi Indonesia sudah meratifikasi berbagai instrument hak asasi internasional yang mengharamkan diskriminasi. Kemajuan Indonesia berdemokrasi hendaknya juga diikuti dengan kemajuan dalam bidang hak asasi manusia sehingga Indonesia akan dilihat sebagi 'island of human rights' yang menjadi tempat yang nyaman dalam pergaulan antar bangsa.

Dalam beberapa hal pemerintah tak perlu terlalu legalistik dalam melihat hak asasi manusia. Pendekatan moralistik bisa pula digunakan karena pendekatan ini akan lebih mengena dalam membangun suatu 'human rights conciousness'. Bagaimanapun kita perlu menyadari bahwa menjamurnya penggunaan kosa kata hak asasi manusia disamping itu suatu langkah spektakuler kemajuan, tetapi juga bisa berbahaya karena bukan saja dapat menjadi 'inflationary' namun sekaligus dikooptasi atau dibajak oleh kekuatan-kekuatan yang dalam dirinya menolak hak asasi manusia. ${ }^{30}$

Semua yang diuraikan diatas adalah wanti-wanti untuk lebih mewaspadai perjalanan hak asasi ke depan tetapi itu semua seharusnya tetap membuat kita bersyukur bahwa amendemen UUD 1945 yang dilakukan pasca Pemilu 1999 adalah suatu 'milestone' dalam sejarah perjalanan bangsa ini. Apa yang tak berhasil kita capai pada jaman Konstituante akhirnya kita capai juga. Dan perdebatan yang terekam dalam merumuskan pasal-pasal hak asasi manusia adalah perdebatan yang bisa disebutkan sebagai 'enlightened construction'. Tanpa bermaksud membahas perdebatan menarik yang terjadi dalam tubuh PAH I BP MPR kami hanya ingin mengutip pendapat Yusuf Muhammad dari fraksi Partai Kebangkitan Bangsa (PKB) yang mengatakan,

\section{Pasal-pasal tentang HAM merupakan wujud dari egaliterianisme dalam melaksanakan kehidupan berbangsa dan bernegara, akan menjadi dasar yang kuat bagi upaya menegakkan hukum, hak dan kesadaran hidup bersama. ${ }^{31}$}

Landasan konstitusional telah dikukuhkan, dan tinggal terpulang kepada kita untuk mewujudkan Indonesia yang bebas dari diskriminasi yang masih kuat berakar dalam kehidupan kita. Tidak mudah memang. Tetapi kita

${ }^{30}$ Larry Cox, "Reflections On Human Rights At Century's End", Dalam Human Rights Dialogue, Winter 2000, Series 2 Number 1, Carnegie Council.

${ }^{31}$ Lihat: Naskah Komprehensif Perubahan Undang Undang Dasar Negera Republik Indonesia Tahun 1945, Buku VIII, hal. 138. 
haras tetap memelihara optimisme untuk bisa mewujudkan bangsa yang hormat terhadap hak asasi manusia. Kalau Afrika Selatan yang ratusan tahun dijajah dengan diskriminasi rasial (apartheid) yang kejam bisa bangkit, maka tak ada alas an untuk tidak bisa keluar dari lingkaran diskriminasi yang kita hadapi. Sebagai penutup izinkan kami mengutip sebagian dari pidato inagurasi Nelson Mandela ketika pada tanggal 10 Mei 1994 dia diangkat sebagai Presiden Afrika Selatan. Berkata Nelson Mandela,

We have, at last, achieved our political emancipation. We pledge ourselves to liberate all our people from the continuing bondage of poverty, deprivation, suffering, gender and other discrimination.

Never, never, and never again shall it be that this beautiful land will again experience the oppression of one by another. ${ }^{32}$

Kalau Afrika Selatan bisa maka tak ada alasan buat Indonesia untuk tidak bisa. Mari kita bangun Indonesia yang bebas dari diskriminasi.

${ }^{32}$ Nelson Mandela, "Long Walk To Freedom", (London: Abacus, 2000), hal. 747. 


\section{Daftar Pustaka}

An Naim, Abdullahi Ahmed. Islam, Islamic Law And Human Rights, dalam Asian Perspectives On Human Rights. Boulder: Westview Press, 1990.

Cox, Larry. Reflections On Human Rights At Century's End dalam Human Rights Dialogue, Winter 2000, Series 2 Number 1.

Darrow, Clarence. Speeches That Changed The World. London: Quercus Publishing Ltd, 2005.

Kleden, Ignas. Porn Bill Threatens Democratic Freedoms. The Jakarta Post, October 8, 2008.

Laporan Investigasi. Jakarta: LBH Jakarta dan Kontras, 2008.

Naskah Komprehensif Perubahan Undang-Undang Dasar Negara Republik Indonesia Tahun 1945, Buku VIII.

Penyeragaman dan Totalisasi Dunia Kehidupan Sebaga Ancaman Terhadap HAM. Jakarta: Imparsial, 2007.

Putusan Mahkamah Konstitusi Nomor 22-24/PVV-VI/2008 tentang Pengujian Undang Undang No. 10 tahun 2008 tentang Pemilu Anggota Dewan Perwakilan Rakyat, Dewan Perwakilan Daerah dan Dewan Perwakilan Rakyat Daerah.

Rancangan Undang Undang Kitab Undang Undang Hukum Pidana.

Rancangan Undang Undang Pornografi: Seniman Akan Ajukan "Judicial Review", Kompas, 22 September 2008.

Soepomo, Sistem Hukum Di Indonesia Sebelum Perang Dunia II. Jakarta:

Pradnya Paramita, 1997.

Todung Mulya Lubis. In Search of Human Rights: Legal-Polotical Dilemas Of Indonesia's New Order, 1996-1990. Jakarta: Gramedia, 1993.

Undang-undang Nomor 39 Tahun 1999 tentang Hak Asasi Manusi. 